\title{
Sorption Studies on Sulphur in Cultivated Soils of Himachal Pradesh
}

\author{
Ajay Sharma $^{1 *}$ and N. K. Sankhyan ${ }^{2}$ \\ ${ }^{1}$ Department of Soil Science, Punjab Agricultural University, Ludhiana, India \\ ${ }^{2}$ Department of Soil Science, CSK HPKV, Palampur, India \\ *Corresponding author
}

\section{A B S T R A C T}

\begin{tabular}{l} 
Ke y w o r d s \\
$\begin{array}{l}\text { Sulphur, Adsorption } \\
\text { and Desorption, } \\
\text { Sulphate, } \\
\text { Freundlich and } \\
\text { Langmuir } \\
\text { isotherms, Sorption } \\
\text { parameters }\end{array}$ \\
\hline Article Info \\
\hline $\begin{array}{l}\text { Accepted: } \\
\text { 26 July 2020 } \\
\text { Available Online: } \\
\text { 10 August } 2020\end{array}$ \\
\hline
\end{tabular}

Sulphur (S) dynamics was studied in the present investigation to assess the $S$ status of the cultivated soils of Himachal Pradesh. Eighty soil samples (0$0.15 \mathrm{~m}$ depth) were collected randomly across different districts of Himachal Pradesh and their S adsorption-desorption behavior was investigated. Results of the study indicated that adsorption of sulphate was more in medium textured soils as compared to coarse textured soils. The sorption capacity of the soils varied widely and followed the order: medium $>$ fine $>$ coarse textured soils. The amounts of sulphate extracted varied considerably among different soils and increased with increase in the amount of $\mathrm{S}$ sorbed. Freundlich isotherm represented better fit for fine and medium textured soils while Langmuir isotherm showed better fit for coarse textured soils. S desorption was analyzed using Langmuir desorption isotherm which depicted the higher desorption capacity of coarse textured soils.

\section{Introduction}

Sulphur (S) is recognized as a key plant nutrient and is essential for the synthesis of the amino acids like cystine, cysteine and methionine, a component of vitamin $\mathrm{A}$ and activates certain enzyme systems in plants. S deficiencies in India are widespread and scattered throughout 120 districts out of 400 districts (Ghosh and Dash, 2012). Removal of Sby crops in India is about $1.26 \mathrm{mt}$ whereas its replenishment through fertilizers is only about $0.76 \mathrm{mt}$ (Tiwari and Gupta, 2006). Further, the recovery of added $\mathrm{S}$ through external sources is also very low, being only 8 to 10 per cent (Hegde and Murthy, 2005). The demand of $\mathrm{S}$ by plants is not persistent with time because it is regulated internally in response to the environmental conditions and stage of plant development. Spools in the soil are extremely dynamic. Available $S$ content in the soil is used as an index to evaluate soil $\mathrm{S}$ fertility status and its involvement towards nutrition of plant. However; understanding of different forms of Sis of much significance in measuring the long-term availability of nutrients and in formulating strong fertilizer recommendations. Both the availability of Sto 
plants and its leaching to lower horizons are affected by adsorption of sulphate. The major transformations of Sin the agriculture system are mineralization, immobilization and oxidation which govern its gains and losses in the soil-plant system through leaching, gas evolution and adsorption in various agroclimatic conditions.

Sulphate sorption properties are significant in soils, as they have a strong influence on its availability to plants and fertilizer retention. The concentration of sulphate in soil solution, as predicted by the sorption/desorption isotherms, provides valuable information on $\mathrm{S}$ accessibility to crop plants (Kimsey et al., 2005). S requirement of plants has become increasingly important in India as well as in world agriculture. However, to achieve high yields, rates of $\mathrm{S}$ fertilizer should be recommended on the basis of available soil $S$ and crop requirement. Considering the importance of sorption behaviour of Sin its availability and distribution of native $S$ in different fractions in soil, the present investigation was planned to monitor the adsorption-desorption of applied $\mathrm{S}$ in soils using Langmuir and Freundlich adsorption isotherm equation.

\section{Materials and Methods}

Eighty soil samples $(0.0-0.15 \mathrm{~m}$ depth) were collected randomly across different districts of Himachal Pradesh and used in the present study (Fig. 1). Himachal Pradesh is characterized with varied climate that fluctuates from semi tropical in lower hills, to semi arctic in the cold deserts areas of Spiti and Kinnaur. State has enormously dissected mountain ranges interspersed with deep gorges and valleys. It is located between latitudes from $30^{\circ} 22^{\prime} 40^{\prime \prime} \mathrm{N}$ to $33^{\circ} 12^{\prime} 40^{\prime \prime} \mathrm{N}$ and longitudes from $75^{\circ} 45^{\prime} 55^{\prime \prime} \mathrm{E}$ to $79^{\circ} 04^{\prime} 20^{\prime \prime} \mathrm{E}$. Large variations in soil types and climatic conditions prevails in the state. Soil samples from almost all the agro-climatic situations across the state were collected to conduct the present study.

\section{Sulphur adsorption}

Five gram of processed soil and $25 \mathrm{ml}$ of gypsum containing increasing concentrations of $S(0,25,50,75,100,150$ and $200 \mu \mathrm{g}$ $\mathrm{S} \mathrm{ml}^{-1}$ as $\mathrm{SO}_{4}{ }^{2-}$ ) were taken in a series of 60 $\mathrm{ml}$ plastic bottles. After shaking for $24 \mathrm{~h}$, the soil suspension was filtered through Whatman No. 42 filter paper. $S$ remaining in the soil solution was determined turbid metrically (Chesnin and Yien, 1950). The quantity of S adsorbed was calculated as the difference between $\mathrm{S}$ added initially and equilibrium $\mathrm{S}$ concentration in the solution (Kumar et al., 2003). The isotherm data were interpreted in terms of the Langmuir and Freundlich equations as given below:

1. Langmuir equation:

$\mathrm{C} /(\mathrm{x} / \mathrm{m})=(1 / \mathrm{Kb})+(\mathrm{C} / \mathrm{b})$

2. Freundlich equation:

$$
\mathrm{x} / \mathrm{m}=\mathrm{aC} \mathrm{C}^{1 / \mathrm{n}}
$$

Where ' $\mathrm{C}$ ' is equilibrium concentration of $\mathrm{SO}_{4}-\mathrm{S}$ in soil solution $\left(\mu \mathrm{g} \mathrm{ml}^{-1}\right)$, ' $\mathrm{x} / \mathrm{m}$ ' is the amount of $\mathrm{SO}_{4}-\mathrm{S}$ adsorbed ( $\mu \mathrm{g} \mathrm{S} \mathrm{g} \mathrm{g}^{-1}$ ), ' $\mathrm{b}$ ' is $\mathrm{SO}_{4}-\mathrm{S}$ adsorption maxima $\left(\mu \mathrm{g} \mathrm{g}^{-1}\right)$, ' $\mathrm{K}$ ' is

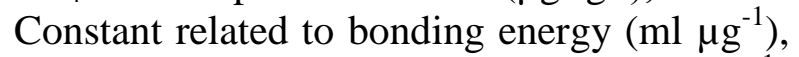
' $\mathrm{a}$ ' is Extent of sulphate adsorption $\left(\mu \mathrm{g} \mathrm{g}^{-1}\right)$ and ' $1 / \mathrm{n}$ ' is Rate of sulphate adsorption. Langmuir parameters like sulphate adsorption maxima (b) and sulphate bonding energy constant (K) were calculated from the intercept and slope, respectively. Amount of S remaining in the solution i.e., equilibrium $\mathrm{S}$ concentration (C) in $\mu \mathrm{g} \mathrm{ml}^{-1}$ was determined turbid metrically using $\mathrm{BaCl}_{2}$.

Amount of sulphate adsorbed $(\mathrm{x} / \mathrm{m})$ in $\mu \mathrm{g} \mathrm{g}^{-1}$ was determined by using the following formula: 


$$
\mathrm{x} / \mathrm{m}=\mathrm{V}(\mathrm{Co}-\mathrm{Ce}) / \mathrm{g} .
$$

Where, ' $\mathrm{x} / \mathrm{m}$ ' is amount of $\mathrm{SO}_{4}-\mathrm{S}$ adsorbed ( $\mu \mathrm{g} \quad \mathrm{S} \mathrm{g}^{-1}$ soil), ' $\mathrm{V}$ ' is volume of the equilibrium solution $(\mathrm{ml})$, ' $\mathrm{Co}$ ' is concentration of $\mathrm{S}$ added to soil $\left(\mu \mathrm{g} \mathrm{ml} \mathrm{m}^{-1}\right)$, ' $\mathrm{Ce}$ ' is equilibrium concentration of $\mathrm{S}$ in solution $\left(\mu \mathrm{g} \mathrm{ml}^{-1}\right)$, ' $\mathrm{g}$ ' is Weight of soil taken (gm). Graphed the data, putting $\mathrm{C} / \mathrm{x} / \mathrm{m}$ on the $\mathrm{y}$-axis and $\mathrm{C}$ on the $\mathrm{x}$-axis. Determined the slope and $y$-intercept of the graph.

Calculated ' $b$ ' using the formula:

$$
\mathrm{b}=1 /(\mathrm{y} \text {-intercept })
$$

Determined the slope by dividing length of the perpendicular by length of the base of the curve.

Calculated ' $\mathrm{K}$ ' using the formula:

$$
\text { Slope }=1 / \mathrm{Kb} \text {. }
$$

Inserted the values for ' $b$ ' and ' $K$ ' into the Langmuir isotherm equation. The Freundlich constants like 'a', ' $1 / \mathrm{n}$ ' and ' $n$ ' were also calculated from intercept and slope of $\log$ $(\mathrm{x} / \mathrm{m})$ versus $\log (\mathrm{C})$ graph, respectively. The procedure for determining intercept and slope was same as mentioned above for Langmuir adsorption parameters. Data so obtained on ' $a$ ' and ' $1 / \mathrm{n}$ ' was inserted to Freundlich adsorption isotherm equation.

\section{Sulphur Desorption}

For sulphur desorption, soils were permitted to adsorb sulphate as in the adsorption studies and the adsorbed sulphate was extracted by shaking for 24 hours with potassium dihydrogen phosphate $\left(\mathrm{KH}_{2} \mathrm{PO}_{4}\right)$ solution containing $500 \mu \mathrm{g} \mathrm{P} \mathrm{ml}{ }^{-1}$ centrifuged and filtered. The amount of Sin the filtrate was measured turbidimetrically using $\mathrm{BaCl}_{2}$. The data obtained on $\mathrm{S}$ desorption were fitted in accordance with a Langmuir type equation: De/Sde $=1 /(\mathrm{Kd}$ x Dm $)+$ De/Dm, Where, 'Sde' is Amount of presorbed $\mathrm{S}$ ( $\mu \mathrm{g} \mathrm{S} \mathrm{g}^{-1}$ soil), 'De' is Amount of $S$ desorbed $\left(\mu \mathrm{g} \mathrm{ml}^{-1}\right)$, 'Dm' is Desorption maxima $\left(\mu \mathrm{g} \mathrm{g}^{-1}\right)$, ' $\mathrm{Kd}$ ' is Desorption constant related to $\mathrm{S}$ mobility in soils $\left(\mathrm{ml} \mathrm{g}^{-1}\right)$.Desorption maxima (Dm) and constant $(\mathrm{Kd})$ were calculated from slope and intercept of linear plot of De/Sde versus De, respectively.

\section{Results and Discussion}

\section{Sulphur Adsorption Parameters}

For the critical examination of the data on sulphur sorption, soil samples were grouped in three categories as per their texture. Samples possessing coarse texture in one category (33 no.), medium texture in second category (38 no.) and fine texture in third category ( 9 no.). The results have been presented and discussed under these categories.

Sulphur adsorption parameters were calculated by fitting the adsorption data into Langmuir and Freundlich equations. A perusal of data in Table 1 revealed that $S$ adsorption had an excellent fit to Langmuir and Freundlich isotherms having $\mathrm{R}^{2}=0.991$ to 0.999 and 0.895 to 0.990 for Langmuir and Freundlich isotherms, respectively.

The mean $\mathrm{R}^{2}$ values of Langmuir were recorded higher than those of Freundlich equation. Aggarwal and Nayyar (2001) reported that adsorption data confirmed very well and was an excellent fit for Langmuir and Freundlich isotherms. The Langmuir coefficients of different textured soils were calculated from the best fitting regression lines. Adsorption maxima ' $b$ ' varied from 226 to $643 \mu \mathrm{g} \mathrm{S} \mathrm{g}^{-1}$, with an average of $423 \pm 106$ $\mu \mathrm{g} \mathrm{S} \mathrm{g}^{-1}$ and with a median of $412 \mu \mathrm{g} \mathrm{S} \mathrm{g}^{-1}$. 
Table.1 Langmuir and Freundlich adsorption parameters for sulphuradsorption in soils

\begin{tabular}{|c|c|c|c|c|c|c|c|c|c|}
\hline \multirow{2}{*}{\multicolumn{2}{|c|}{ Category }} & \multicolumn{4}{|c|}{ Langmuir equation } & \multicolumn{4}{|c|}{ Freundlich equation } \\
\hline & & \multirow{2}{*}{$\begin{array}{c}\mathbf{b} \\
\left(\boldsymbol{\mu g} \mathbf{~ g}^{-1}\right) \\
226-643\end{array}$} & \multirow{2}{*}{$\begin{array}{c}\begin{array}{c}\mathbf{k} \\
\left(\mathbf{m l ~}^{\mu \mathbf{g}^{-1}}\right)\end{array} \\
0.01-0.04\end{array}$} & \multirow{2}{*}{$\begin{array}{c}\text { MBC (b x k) } \\
\left(\mathbf{m l ~ g}^{-\mathbf{1}}\right) \\
2.26-12.8\end{array}$} & \multirow{2}{*}{$\begin{array}{c}\mathbf{R}^{\mathbf{2}} \\
0.994-0.999\end{array}$} & \multirow{2}{*}{$\begin{array}{c}\mathbf{a} \\
\left(\mu \mathrm{g} \mathrm{g}^{-1}\right) \\
10.5-28.7\end{array}$} & \multirow{2}{*}{$\begin{array}{c}\begin{array}{c}\mathbf{1 / n} \\
\left(\mathrm{g} \mathrm{ml}^{-1}\right)\end{array} \\
0.25-0.62\end{array}$} & \multirow{2}{*}{$\begin{array}{c}\mathbf{n} \\
1.60-3.05\end{array}$} & \multirow{2}{*}{$\begin{array}{c}\mathbf{R}^{2} \\
0.92- \\
0.982 \\
\end{array}$} \\
\hline $\begin{array}{c}\text { Coarse } \\
\text { textured }\end{array}$ & Range & & & & & & & & \\
\hline$(\mathbf{n}=\mathbf{3 3})$ & Mean & 388 & 0.02 & 5.35 & 0.998 & 20.5 & 0.573 & 1.65 & 0.952 \\
\hline & Median & 377 & 0.01 & 4.85 & 0.998 & 21.9 & 0.594 & 1.63 & 0.956 \\
\hline & $\mathbf{S D}( \pm)$ & 117 & 0.007 & 2.22 & 0.001 & 5.07 & 0.037 & 0.41 & 0.019 \\
\hline \multirow{4}{*}{$\begin{array}{c}\text { Medium } \\
\text { textured } \\
(n=38)\end{array}$} & Range & $274-641$ & $0.01-0.04$ & $2.91-20.1$ & $0.991-0.999$ & $13.2-38.3$ & $0.25-0.62$ & $1.61-3.92$ & $\begin{array}{c}0.895- \\
0.990\end{array}$ \\
\hline & Mean & 457 & 0.02 & 9.31 & 0.997 & 24.6 & 0.525 & 1.97 & 0.962 \\
\hline & Median & 468 & 0.02 & 9.26 & 0.998 & 22.7 & 0.539 & 1.86 & 0.966 \\
\hline & $\mathbf{S D}( \pm)$ & 82 & 0.010 & 4.72 & 0.001 & 7.45 & 0.084 & 0.46 & 0.017 \\
\hline \multirow{4}{*}{$\begin{array}{c}\text { Fine } \\
\text { textured } \\
(\mathbf{n}=9)\end{array}$} & Range & $274-592$ & $0.01-0.04$ & $2.84-21.6$ & 0.994-0.999 & $13.1-37.5$ & $0.32-0.57$ & $1.68-3.17$ & $\begin{array}{r}0.964- \\
0.983\end{array}$ \\
\hline & Mean & 409 & 0.02 & 7.45 & 0.997 & 23.8 & 0.565 & 1.90 & 0.961 \\
\hline & Median & 394 & 0.02 & 5.54 & 0.998 & 22.6 & 0.573 & 1.74 & 0.965 \\
\hline & $\mathbf{S D}( \pm)$ & 117 & 0.009 & 5.66 & 0.001 & 7.86 & 0.031 & 0.44 & 0.020 \\
\hline \multirow[t]{4}{*}{ Overall } & Range & $226-643$ & $0.01-0.04$ & $2.26-21.6$ & 0.991-0.999 & $10.5-38.3$ & $0.25-0.62$ & $1.60-3.92$ & $\begin{array}{c}0.895- \\
0.990\end{array}$ \\
\hline & Mean & 423 & 0.02 & 7.47 & 0.997 & 22.8 & 0.550 & 2.02 & 0.955 \\
\hline & Median & 412 & 0.02 & 5.77 & 0.998 & 22.3 & 0.570 & 1.89 & 0.959 \\
\hline & $\mathbf{S D}( \pm)$ & 106 & 0.009 & 4.38 & 0.001 & 6.81 & 0.067 & 0.43 & 0.019 \\
\hline
\end{tabular}


Table.2 Sulphur adsorption and desorption $\left(\mu \mathrm{g} \mathrm{S} \mathrm{g}^{-1}\right)$ in different soils and Langmuir desorption parameters for $\mathrm{S}$ desorption in soils

\begin{tabular}{|c|c|c|c|c|c|c|c|c|c|c|c|c|c|c|c|c|}
\hline \multirow{2}{*}{\multicolumn{2}{|c|}{ Category }} & \multicolumn{6}{|c|}{ Adsorption $S$ added $\left(\mu \mathrm{g} S \mathrm{~g}^{-1}\right)$} & \multirow{2}{*}{\multicolumn{6}{|c|}{ Desorption $S$ added $\left(\mu \mathrm{g} S \mathrm{~g}^{-1}\right)$}} & \multicolumn{3}{|c|}{ Langmuir desorption } \\
\hline & & \multirow{2}{*}{$\begin{array}{c}125 \\
43.9- \\
68.8\end{array}$} & \multirow{2}{*}{$\begin{array}{c}250 \\
64.4- \\
99.4\end{array}$} & \multirow{2}{*}{$\begin{array}{c}375 \\
95.7- \\
124\end{array}$} & \multirow{2}{*}{$\begin{array}{c}\mathbf{5 0 0} \\
113- \\
139\end{array}$} & \multirow{2}{*}{$\begin{array}{c}750 \\
138- \\
167\end{array}$} & \multirow{2}{*}{$\begin{array}{c}1000 \\
149- \\
178\end{array}$} & & & & & & & \multirow{2}{*}{$\begin{array}{c}\text { Dm } \\
\left(\boldsymbol{\mu g \mathbf { g } ^ { - 1 } )}\right. \\
222-885\end{array}$} & \multirow{2}{*}{$\begin{array}{c}\mathbf{K d} \\
\left(\mathbf{m l ~ g}^{-1}\right)\end{array}$} & \multirow{2}{*}{$\begin{array}{c}\mathbf{R}^{2} \\
0.990- \\
0.999\end{array}$} \\
\hline $\begin{array}{l}\text { Coarse } \\
\text { textured }\end{array}$ & Range & & & & & & & $\begin{array}{l}125 \\
11.3- \\
23.0\end{array}$ & $\begin{array}{c}250 \\
26.8- \\
43.6\end{array}$ & $\begin{array}{c}375 \\
43.5- \\
66.5\end{array}$ & $\begin{array}{c}\mathbf{5 0 0} \\
53.6- \\
75.3\end{array}$ & $\begin{array}{c}750 \\
72.3- \\
98.8\end{array}$ & $\begin{array}{c}1000 \\
80.8- \\
115\end{array}$ & & & \\
\hline & Mean & 55.1 & 85.5 & 107 & 124 & 151 & 165 & 17.5 & 34.2 & 54.2 & 66.1 & 85.0 & 99.2 & 596 & 0.008 & 0.995 \\
\hline & Median & 53.8 & 87.2 & 106 & 124 & 151 & 168 & 17.8 & 33.3 & 54.0 & 67.1 & 83.6 & 98.3 & 621 & 0.007 & 0.995 \\
\hline & $\operatorname{SD}( \pm)$ & 5.65 & 7.54 & 7.20 & 5.84 & 7.49 & 8.48 & 3.01 & 3.76 & 4.94 & 5.22 & 7.18 & 7.70 & 224 & 0.005 & 0.002 \\
\hline \multirow{4}{*}{$\begin{array}{l}\text { Medium } \\
\text { textured } \\
(n=38)\end{array}$} & Range & $\begin{array}{l}59.6- \\
77.4\end{array}$ & $\begin{array}{c}105- \\
109\end{array}$ & $\begin{array}{l}141- \\
197\end{array}$ & $\begin{array}{l}155- \\
244\end{array}$ & $\begin{array}{l}176- \\
281\end{array}$ & $\begin{array}{l}189- \\
318\end{array}$ & $\begin{array}{l}12.0- \\
22.2\end{array}$ & $\begin{array}{l}27.0- \\
53.7\end{array}$ & $\begin{array}{l}43.5- \\
75.2\end{array}$ & $\begin{array}{c}57.5- \\
102\end{array}$ & $78.6-127$ & $\begin{array}{c}87.8- \\
146\end{array}$ & $227-901$ & $\begin{array}{c}0.003- \\
0.021\end{array}$ & $\begin{array}{c}0.989- \\
0.999\end{array}$ \\
\hline & Mean & 67.9 & 124 & 168 & 201 & 244 & 270 & 17.2 & 37.7 & 57.9 & 76.1 & 102 & 121 & 529 & 0.010 & 0.994 \\
\hline & Median & 67.7 & 124 & 168 & 201 & 248 & 273 & 16.9 & 37.4 & 57.6 & 76.9 & 101 & 121 & 485 & 0.008 & 0.995 \\
\hline & $\operatorname{SD}( \pm)$ & 4.06 & 8.78 & 12.8 & 17.0 & 23.8 & 28.9 & 2.70 & 5.56 & 7.19 & 9.09 & 11.5 & 13.4 & 198 & 0.005 & 0.003 \\
\hline \multirow{4}{*}{$\begin{array}{c}\text { Fine } \\
\text { textured } \\
(\mathbf{n}=9)\end{array}$} & Range & $\begin{array}{c}60.9- \\
70.4\end{array}$ & $\begin{array}{l}110- \\
133\end{array}$ & $\begin{array}{l}141- \\
175\end{array}$ & $\begin{array}{l}162- \\
215\end{array}$ & $\begin{array}{l}182- \\
255\end{array}$ & $\begin{array}{l}191- \\
284\end{array}$ & $\begin{array}{l}15.4- \\
21.5\end{array}$ & $\begin{array}{l}35.7- \\
51.3\end{array}$ & $\begin{array}{l}58.3- \\
75.7\end{array}$ & $\begin{array}{c}73.9- \\
102\end{array}$ & $90.1-127$ & $\begin{array}{c}100- \\
148\end{array}$ & $218-826$ & $\begin{array}{c}0.004- \\
0.016\end{array}$ & $\begin{array}{c}0.983- \\
0.995\end{array}$ \\
\hline & Mean & 64.6 & 117 & 154 & 183 & 219 & 240 & 18.7 & 42.4 & 65.8 & 85.6 & 109 & 129 & 480 & 0.011 & 0.989 \\
\hline & Median & 72.9 & 135 & 183 & 225 & 282 & 315 & 18.7 & 41.3 & 65.4 & 83.5 & 112 & 134 & 513 & 0.009 & 0.989 \\
\hline & $\operatorname{SD}( \pm)$ & 3.40 & 7.59 & 9.94 & 14.9 & 23.1 & 29.3 & 1.88 & 4.81 & 5.62 & 8.48 & 12.8 & 16.2 & 193 & 0.004 & 0.003 \\
\hline \multirow[t]{4}{*}{ Overall } & Range & $\begin{array}{c}43.9- \\
77.4\end{array}$ & $\begin{array}{c}64.4- \\
149\end{array}$ & $\begin{array}{c}95.7- \\
197\end{array}$ & $\begin{array}{l}113- \\
244\end{array}$ & $\begin{array}{l}138- \\
282\end{array}$ & $\begin{array}{l}149- \\
318\end{array}$ & $\begin{array}{l}11.3- \\
23.0\end{array}$ & $\begin{array}{c}26.8- \\
53.6\end{array}$ & $\begin{array}{l}43.5- \\
75.7\end{array}$ & $\begin{array}{c}53.6- \\
102\end{array}$ & $72.3-127$ & $\begin{array}{c}80.8- \\
148\end{array}$ & $218-901$ & $\begin{array}{c}0.001- \\
0.025\end{array}$ & $\begin{array}{c}0.983- \\
0.999\end{array}$ \\
\hline & Mean & 62.3 & 107 & 141 & 167 & 203 & 223 & 17.5 & 36.8 & 57.3 & 73.0 & 95.7 & 113 & 551 & 0.010 & 0.994 \\
\hline & Median & 63.6 & 115 & 151 & 183 & 209 & 231 & 17.8 & 36.3 & 55.9 & 71.3 & 93.5 & 110 & 541 & 0.009 & 0.995 \\
\hline & $\mathbf{S D}( \pm)$ & 7.67 & 20.0 & 30.8 & 39.3 & 48.2 & 54.6 & 2.76 & 5.41 & 7.04 & 9.98 & 13.7 & 16.3 & 210 & 0.006 & 0.003 \\
\hline
\end{tabular}


Fig.1 Soil sampling sites

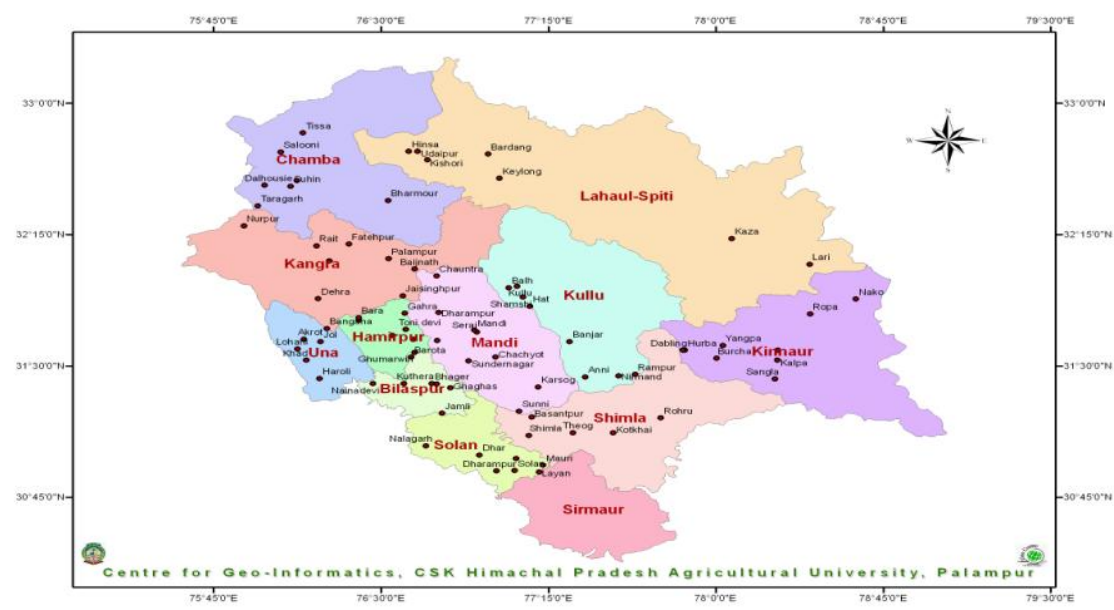

Fig.2 Adsorption of $\mathrm{S}$ at varying equilibrium $\mathrm{S}$ concentration in soils
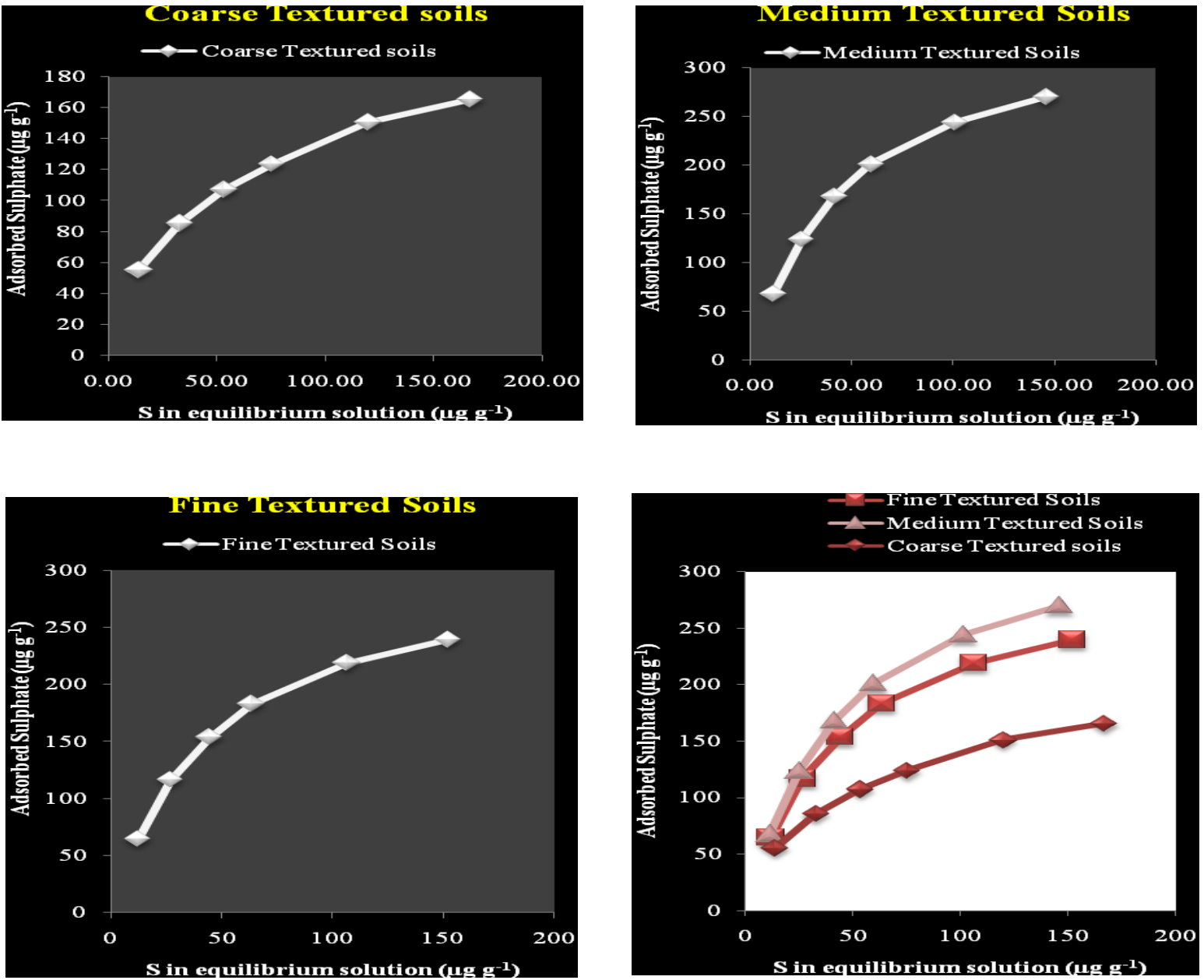
Fig.3 Langmuir isotherm of S desorption in soils
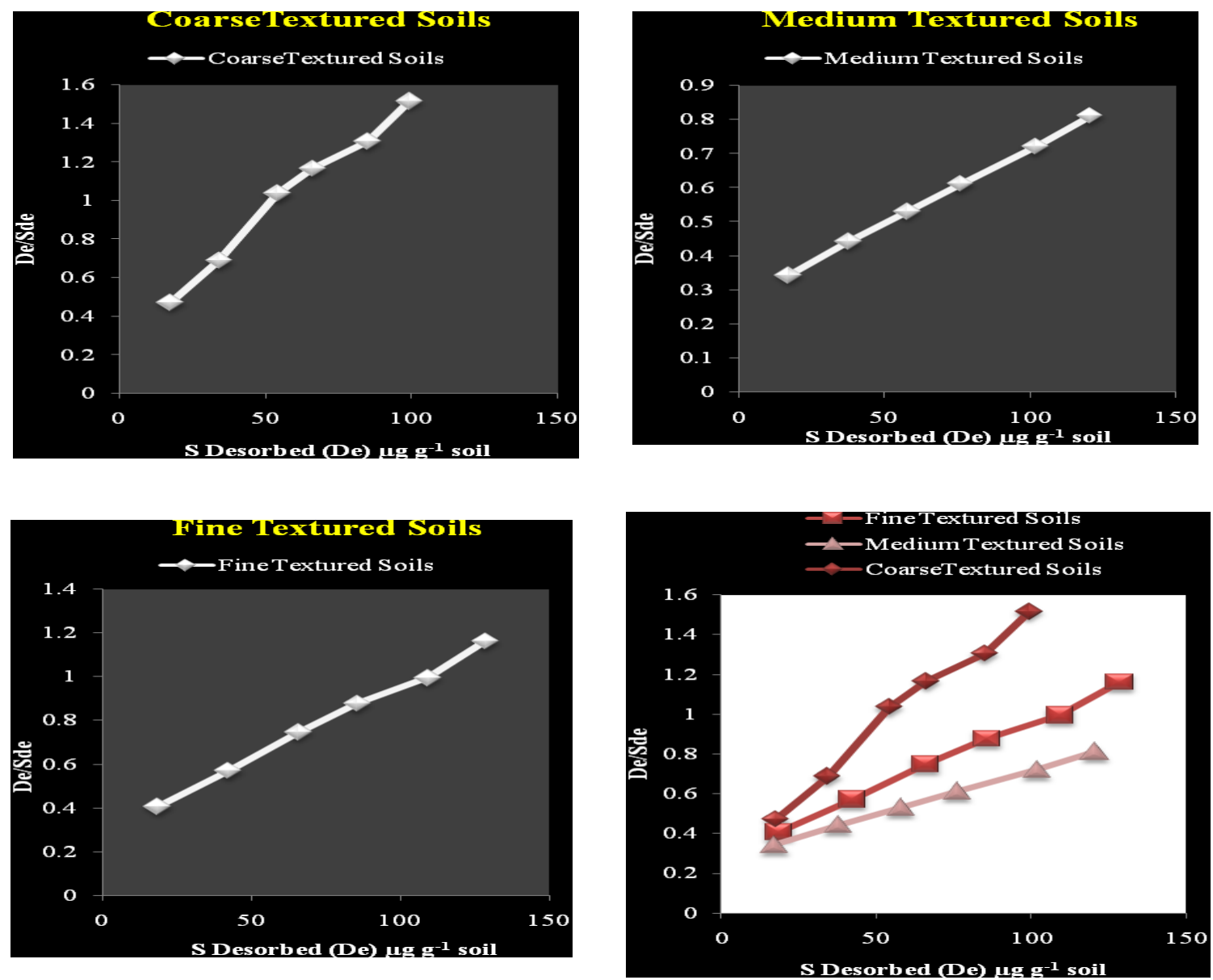

The values of affinity coefficient i.e. bonding energy ' $\mathrm{k}$ ' ranged from 0.01 to $0.04 \mathrm{ml}^{\mathrm{g}} \mathrm{g}^{-1}$ having mean value of $0.02 \pm 0.009 \mathrm{ml}^{-1} \mathrm{~g}^{-1}$. Similarly, the maximum buffering capacity (MBC) varied from 2.26 to $21.6 \mathrm{ml} \mathrm{g}^{-1}$ with an average of $7.47 \pm 4.38 \mathrm{ml} \mathrm{g}^{-1}$. The wide variation in these parameters might be attributed to differences in the physical, chemical and mineralogical properties and could be attributed to the effect of organic matter. Similar results were reported by Das et al., (2002) and Borkotoki and Das (2007). Value of ' $a$ ' in medium textured soils varied from 13.2 to $38.3 \mu \mathrm{g} \mathrm{g}^{-1}$ with an average of $24.6 \pm 7.45 \mu \mathrm{g} \mathrm{g}^{-1}$ which was the highest in the three kind of soils, representing the

highest adsorption capacity of medium textured soils. These results supported the findings of Setia et al., (2005). Values of the Freundlich constant ' $1 / \mathrm{n}$ ' were less than unity in all the soils, which indicated the existence of L-shaped isotherm. These results were in conformity with the findings of Ghosh and Dash (2012).

\section{Adsorption of sulphurin different soils}

Adsorption of sulphur varied markedly among the soil samples from different locations having differed textural features. Data in Table 2 revealed that on an average adsorbed Sranged between43.9 to 77.4, 64.4 to 
$149,95.7$ to 197,113 to 244,138 to 282 and 149 to $318 \mu \mathrm{g} \mathrm{S} \mathrm{g}^{-1}$ with an average value of $62.3 \pm 7.67,107 \pm 20.0,141 \pm 30.8,167 \pm$ $39.3,203 \pm 48.2$ and $223 \pm 54.6 \mu \mathrm{g} \mathrm{S} \mathrm{g}^{-1}$ with the incremental doses of $\mathrm{S} @ 125,250,375$, 500, 750 and $1000 \mu \mathrm{g} \mathrm{S} \mathrm{g}{ }^{-1}$ soil, respectively. A perusal of Figure 2 revealed that adsorption in medium textured soils was strikingly higher than fine textured and coarse textured soils. Higher adsorption might be due to the effect of lower organic matter in medium textured soils than fine textured soils. Coarse textured soils exhibited the lower adsorption which might be attributed due to high sand content and thus less adsorption sites.The results revealed that with the escalation in sulphate concentration in equilibrium solution, the amount of sulphate adsorbed by soils increased. Similar results were reported by Murthy (2004).

\section{Desorption of Sulphurin Different Soils}

The degree of the reversibility is a direct measure of sulphur availability and should be compared with sulphate adsorption behavior of soils to reach at a meaningful conclusion. Sulphate desorption study was done by using the soil left after adsorption studies and the data so obtained have been presented in Table 2. Results showed that desorbed sulphate was far less than that of adsorbed sulphate. A perusal of data revealed that desorbed $S$ in different textured soils ranged between 11.3 to $23.0,26.8$ to $53.6,43.5$ to $75.7,53.6$ to $102,72.3$ to 127 and 80.8 to $148 \mu \mathrm{g} \mathrm{S} \mathrm{g}^{-1}$ with an average value of $17.5 \pm 2.76,36.8 \pm 5.41$, $57.3 \pm 7.04,73.0 \pm 9.98,95.7 \pm 13.7$ and 113 $\pm 16.3 \mu \mathrm{g} \mathrm{S} \mathrm{g}^{-1}$ with the incremental doses of $\mathrm{S}$ @ 125, 250, 375, 500, 750 and $1000 \mu \mathrm{g} \mathrm{S} \mathrm{g}$ ${ }^{1}$ soil, respectively. Amount of $\mathrm{S}$ desorbedin fine textured soils was recorded strikingly higher than medium and coarse textured soils. This might be due to the effect of high organic matter and active iron and aluminum ratio in fine textured soils as also pointed out by the Douli and Jana (1997) and Kumar et al (2003).

Langmuir desorption parameters such as desorption maxima (Dm) and constant related to desorbed S mobility $(\mathrm{Kd})$ were worked out from the linear plots of De vs. De/S (Fig. 3). Desorption maxima (Dm) indicates the maximum desorbable capacity of the soils. Lesser the desorption maxima value (Dm), more is the potential of soil to release $S$ to meet the requirements of the crop. A linear relation was obtained in all the soils when sulphate desorbed (De) was plotted against desorbed sulphate/adsorbed sulphate (De/S) for different type soils. The values of $\mathrm{R}^{2}$ varied as 0.990 to $0.999,0.989$ to 0.999 and 0.983 to 0.995 for coarse, medium and fine textured soils, respectively. The smaller the $\mathrm{Kd}$ value, less is the desorption of sulphur, thereby, suggesting a need for fertilization in soils (Dutta, 2009).

On the bases of foregoing results; it can be concluded that both Langmuir and Freundlich adsorption isotherm showed maximum adsorption capacity in case of medium textured soils. Amount of adsorbed S by soils improved with escalation in concentration. Freundlich isotherm represented better fit for fine and medium textured soils while Langmuir isotherm showed better fit for coarse textured soils. During desorption of $\mathrm{S}$, the amount of sulphate desorbed was always inferior than the amount of sulphate adsorbed during sorption, however, the desorbed amounts increased in proportion to amounts of sulphate adsorbed.

\section{Acknowledgement}

Authors are obliged to the Department of Soil Science for providing the technical sport to carry out this research work at CSK HPKV, Palampur, Himachal Pradesh. 


\section{References}

Aggarwal, V., and Nayyar, V.K.2001. Effect of organic amendments on the adsorption and desorption of sulhate sulphur in a typic Ustochrept soil. J. Res. Punjab Agri. Univ., 38:162-167.

Borkotoki, B., and Das, K.N. 2007.Sulphate sorption and buffering capacity in some soils of Assam. J. Indian Soc. Soil Sci., 55: 127-133.

Chesnin, L., and Yien C.H. 1950. Turbidimetric determination of available sulphate.Soil Sci. Soc.Am. Proc., 15: 149-151.

Das, P.K., Sahu, S.K., and Acharyya, N. 2002.Effect of organic matter on sulphate adsorption in some Alfisols of Orissa. J. Indian Soc. Soil Sci., 50: 2328.

Douli, A.K., and Jana, S.C. 1997.Sulphate sorption desorption characteristics of some Inceptisols. J. Indian Soc. Soil Sci., 45: 265-270.

Dutta, J. 2009. Long-term effect of chemical fertilizers and amendments on sulphur sorption under maize-wheat system. M.Sc. The is. Department of Soil Science, CSK Himachal Pradesh Krishi Vishavidyalaya, Palampur, India.

Ghosh, G.K., and Dash, N.R. 2012.Sulphate sorption-desorption characteristics of lateritic soils of West Bengal. Int. J. Plant Animal Environ. Sci., 168-176.

Hegde, D.M., and Murthy, I.Y.L.N. 2005. Management of secondary nutrientsachievements and challenges. Indian J.Fert., 1: 93-100.

Kimsey, M., McDaniel, P., Strawn, D., and Moore, J. 2005.Fate of applied sulphate in volcanic ash-influenced forest soils. Soil Sci. Soc.Am. J., 69: 1507-1515.

Kumar, R., Singh, K.P., Sarkar, A.K., Wadood, A., and Singh, S. 2003. Sulphate sorption characteristics of Alfisols of Dumka district (Jharkhand). J. Indian Soc. Soil Sci., 51: 512-517.

Murthy, I.Y.L.N. 2004.Sulphate sorption studies in some shrink-swell soils. Directorate of Oilseeds Research. Agropedology, 14: 55-59.

Setia, R. K., Sharma, K.N., and Sharma, P.K. 2005.Sulphur adsorption by soil after differential fertilization for twenty two years with NPK under a continuous maize-wheat cropping system. J. Indian Soc. Soil Sci., 53: 417-420.

Tiwari, K.N. and Gupta, B.R. 2006.Sulphur for sustainable high yield agriculture in Uttar Pradesh. Indian J. Fert., 1: 37-52.

\section{How to cite this article:}

Ajay Sharma and Sankhyan, N. K. 2020. Sorption Studies on Sulphur in Cultivated Soils of Himachal Pradesh. Int.J.Curr.Microbiol.App.Sci. 9(08): 3376-3384.

doi: https://doi.org/10.20546/ijcmas.2020.908.390 